\title{
Mountain birch - potentially large source of sesquiterpenes into high latitude atmosphere
}

\author{
S. Haapanala ${ }^{1}$, A. Ekberg ${ }^{2}$, H. Hakola ${ }^{3}$, V. Tarvainen ${ }^{3}$, J. Rinne ${ }^{1}$, H. Hellén ${ }^{3}$, and A. Arneth ${ }^{2,1}$ \\ ${ }^{1}$ Department of Physics, University of Helsinki, Helsinki, Finland \\ ${ }^{2}$ Department of Physical Geography and Ecosystems Analysis, Lund University, Lund, Sweden \\ ${ }^{3}$ Air Quality Research, Finnish Meteorological Institute, Helsinki, Finland
}

Received: 29 April 2009 - Published in Biogeosciences Discuss.: 2 June 2009

Revised: 19 November 2009 - Accepted: 23 November 2009 - Published: 27 November 2009

\begin{abstract}
Emissions of volatile organic compounds (VOCs) from mountain birches were measured in Abisko, northern Sweden. Mountain birches make up the majority of the tree biomass in Scandinavian high latitudes, a region subject to significant climate warming. The measurements were carried out in two growing seasons. The emissions of four branches, each from a different individual tree, were measured in June-August 2006 and one of them again in July 2007. The measurements were conducted using a dynamic flow through chamber covered with Teflon film. The studied mountain birches were found to emit substantial amounts of linalool, monoterpenes and sesquiterpenes. The monoterpene emission was dominated by sabinene. The magnitude and composition of the sesquiterpene emission changed dramatically between the years. For example, the average $\alpha$-farnesene emission potential in 2006 was almost $2600 \mathrm{ng} \mathrm{g}_{\mathrm{dw}}^{-1} \mathrm{~h}^{-1}\left(3.5 \mathrm{pmol} \mathrm{g}_{\mathrm{dw}}^{-1} \mathrm{~s}^{-1}\right)$ while in $2007 \alpha$ farnesene was not detected at all. Also the emissions of other sesquiterpenes decreased in 2007 to a fraction of that in 2006. One possible explanation for the change in emissions is the herbivory damage that occurred in the area in 2004. Herbivory is known to enhance the emissions of sesquiterpenes, especially those of $\alpha$-farnesene, and the effect may last for several years.
\end{abstract}

\section{Introduction}

Volatile organic compounds (VOCs) are a diverse group of hydrocarbons emitted to the atmosphere from both biogenic and anthropogenic sources (Guenther et al., 1995; Simpson

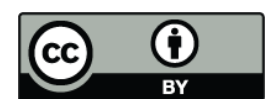

Correspondence to: S. Haapanala (sami.haapanala@helsinki.fi) et al., 1999; Piccot et al., 1992). Their double bonds give rise to high reactivities towards the hydroxyl radical $(\mathrm{OH})$, ozone $\left(\mathrm{O}_{3}\right)$, and the nitrate radical $\left(\mathrm{NO}_{3}\right)$. Therefore the volatile organic compounds play an essential role in the regulation of the oxidizing capacity of the atmosphere. The VOCs also contribute to the formation and growth of secondary organic aerosols (Kulmala et al., 2004; Tunved et al., 2006), and they may form long-lived oxidation products, with the potential of affecting atmospheric chemistry in remote regions (Law and Stohl, 2007).

Biogenic VOC emissions in the tropical, temperate and boreal vegetation zones have been extensively studied while the high-latitude, e.g. subarctic, ecosystems have gained much less attention (Tiiva et al., 2008; Bäckstrand et al., 2008; Ekberg et al., 2009). However, the subarctic vegetation zone covers large areas on the globe, and despite its relatively low biomass density it can have a significant impact on atmospheric VOC concentrations, especially on local to regional scales. Largely as a result of the prevalence of short and cool summers, biogenic VOC (BVOC) emissions from the northern regions are likely to be relatively small compared to the global emissions. However, atmospheric reactions such as particle formation from biogenic pre-cursors and ozone destruction/formation occur on regional rather than global spatial scales (e.g. Tunved et al., 2006; Svenningsson et al., 2008).

Mountain birch (Betula pubescens ssp. czerepanovii (Orlova) Hämet-Ahti), a subspecies of downy birch, covers an area of almost 600000 ha in the Scandinavian subarctic. The birch species in boreal and temperate regions have been found to emit substantial amounts of a wide range of $\mathrm{C}_{5}$ to $\mathrm{C}_{15}$ VOCs (Isidorov et al., 1985; König et al., 1995; Hakola et al., 1998, 2001; Vuorinen et al., 2005). BVOCs emitted from the mountain birch in the subarctic may thus be of significant regional importance for the complex relationship

Published by Copernicus Publications on behalf of the European Geosciences Union. 
between the ecosystem carbon flux, atmospheric chemistry and climate, but at the present there is only one study available of their emissions (Steinbrecher et al., 1999).

The subarctic mountain birch forests are exposed to herbivory by caterpillars of the autumnal moth (Epirrita autumnata), and severe outbreaks occur on a regular basis with intervals of about 9-10 years. In some cases, large forest areas have suffered from mortality of most of the trees (Trägårdh, 1939; Haukioja et al., 1988). Mechanical damage of leaf tissue is known to induce an immediately enhanced production and emission of volatiles (Juuti et al., 1990). However, it has also been suggested that an immunological memory effect of herbivore attacks, potentially affecting the composition of the emitted VOC mixture, may persist for several years after the actual defoliation event (Ruuhola et al., 2007).

The aim of the present study is to characterize the VOC emissions from a natural mountain birch forest. To obtain the emission parameters that could be further exploited in emission inventories and emission model development, the temperature and the photosynthetic photon flux density (PPFD) were carefully recorded during the measurements. In addition to the VOC emission measurements, ecosystem scale photosynthesis was measured simultaneously at the same site. From these data we also managed to study the link between delayed responses of herbivory damage and the atmospheric VOC emissions of plants.

\section{Materials and methods}

\subsection{Measurement site}

The measurements took place in the Stordalen Nature Reserve, located near Abisko in northern Sweden $\left(68^{\circ} 20^{\prime} \mathrm{N}\right.$, $19^{\circ} 03^{\prime} \mathrm{E}, 360 \mathrm{~m}$ a.s.l.). The long-term annual mean temperature at the Abisko climate station $\left(68^{\circ} 21^{\prime} \mathrm{N}, 18^{\circ} 49^{\prime} \mathrm{E}\right.$, $388 \mathrm{~m}$ a.s.1.) is $-0.8^{\circ} \mathrm{C}$ with the warmest month being July (mean temperature $11.0^{\circ} \mathrm{C}$ ) and the coldest January (mean temperature $-11.9^{\circ} \mathrm{C}$ ). The sheltered valley has a relatively dry microclimate with a mean annual precipitation of $304 \mathrm{~mm}$. The highest precipitation occurs in July (mean rainfall $54 \mathrm{~mm}$ ) and the lowest in April (mean rainfall $12 \mathrm{~mm}$ ) (Alexandersson et al., 1991). Snow accounts for about half of the precipitation.

The woody vegetation at the measurement site is dominated by mountain birch. The forest is limited by a mire in the north and continues in the other directions for hundreds of meters. There is a road with little traffic to the south of the measurement site. During the growing season of 2004 the area was affected by a massive outbreak of the autumnal moth. By the growing season of 2006, the trees had mostly recovered from the damage caused by the outbreak. The net $\mathrm{CO}_{2}$ exchange in 2006 was of the same order of magnitude as in the growing seasons preceding the outbreak in 2004
(T. Johansson, Torbjörn Johansson, Lund University, Lund, Sweden, personal communication, 2009).

In summer 2006 we conducted VOC emission measurements on four individual trees (numbered as 1-4) and, as a complementary measurement, one of them (number 4) was measured again in summer 2007. The measurements took place during 28 June-5 August 2006 and during 16-17 July 2007. The dataset of the year 2006 consists of 40 chamber closure measurements and that of 2007 consists of 16 chamber closure measurements. During both of the campaigns the leaves of the studied trees were mature. Due to the fact that all the measurements were conducted in the middle of the growing season, the seasonal variation of the emissions was not studied.

\subsection{Sampling}

For the VOC emission measurements a branch growing about $2 \mathrm{~m}$ above the ground level was placed in a transparent chamber made of Teflon film. The canopy is open and at that height, about half of total tree-height, the branch is sunexposed. The enclosure installation took place at least one day before the measurements to avoid any effects of rough handling of the plant on the emission which has been shown to cause increased emissions (e.g. Juuti et al., 1990; König et al., 1995; Hakola et al., 2001). The enclosure was appropriately ventilated until just prior to sampling initiation. The volume of the cylindrical enclosure was about 151 . Inflowing air was pumped to the enclosure at a rate of about $51 \mathrm{~min}^{-1}$. Ozone was removed from the inflow air using $\mathrm{MnO}_{2}$ coated copper nets. Samples from both the inflow and outflow air were collected by trapping $\mathrm{C}_{5}-\mathrm{C}_{15}$ hydrocarbons into cartridges filled with Tenax-TA and Carbopack-B/Carbograph 1TD adsorbents. The samples were taken using a constant flow rate of about 0.1 to 0.2 litres per minute and sampling times of 55 to 120 minutes resulting in a 6 to 12 liter sample volume. The adsorbent samples were analyzed using an automatic thermodesorption device (Perkin-Elmer ATD-400) connected to a gas chromatograph (HP-5890), with a massselective detector (HP-5972). The precision of the repeated adsorbent calibration sample analysis was estimated to be about $6 \%$ for each compound. This value was used as an estimate for the repeatability of the concentration measurements. The emission rates were determined based on differences in concentration between inlet and outlet air. For further description of the enclosure system and chemical analysis, see Hakola et al. (2001, 2006).

Despite the relatively high air flow through the enclosure, the temperature inside the enclosures increased during periods of strong solar radiation. The highest recorded temperature inside the enclosures was $31.4^{\circ} \mathrm{C}$, with the corresponding ambient temperature being $18.0^{\circ} \mathrm{C}$. During the measurements the temperature difference between the enclosure and the ambient air varied from 0 to $15^{\circ} \mathrm{C}$, with the average 

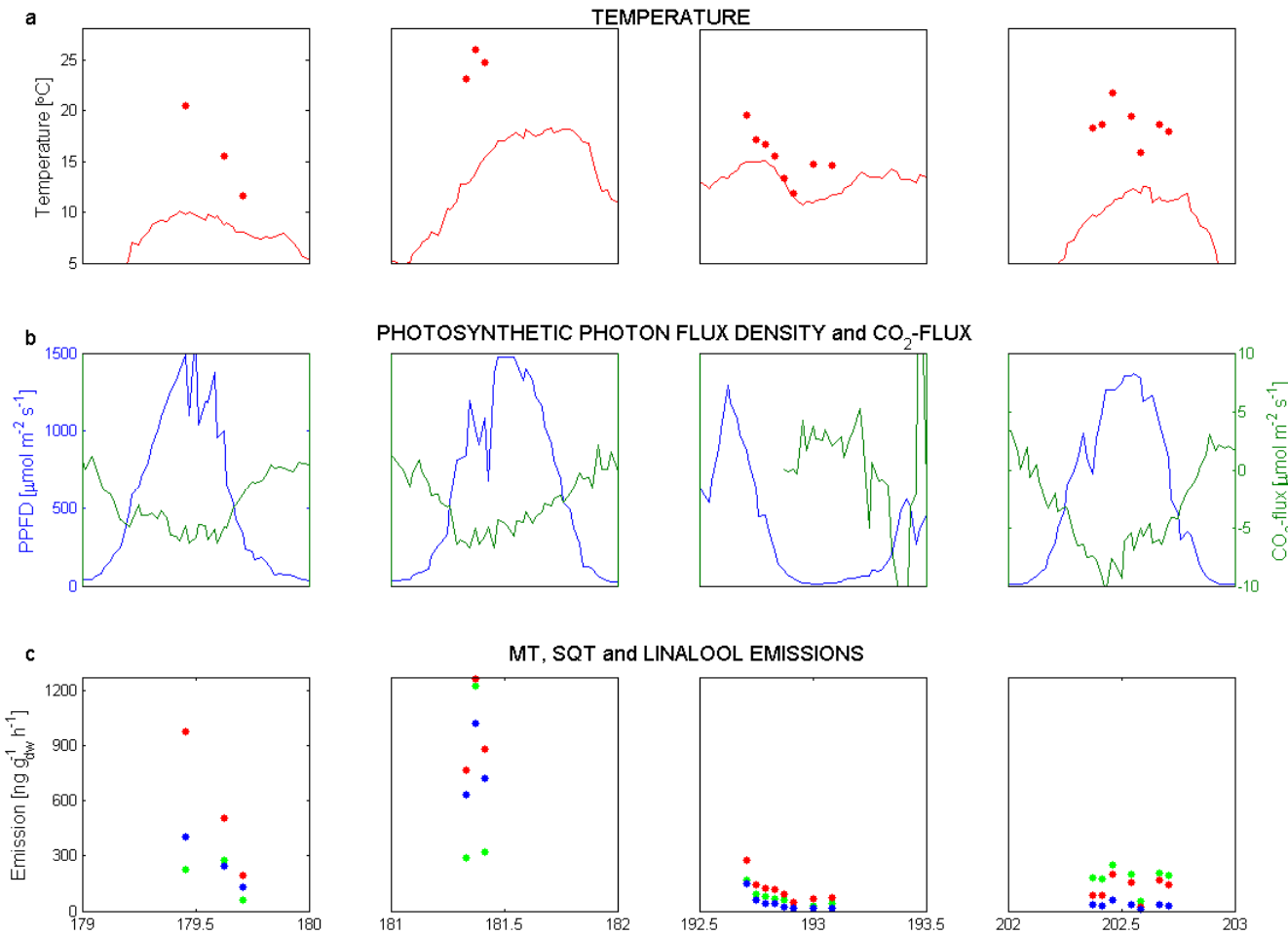

Fig. 1. A time series of the meteorological variables together with the ecosystem scale $\mathrm{CO}_{2}$ flux and the emissions of different VOC groups from birch number 1. The upper panels (a) show the temperature measured inside the chamber (red dots) and in ambient air (red line). The middle panels (b) show the photosynthetic photon flux density (blue line) and the ecosystem scale $\mathrm{CO}_{2}$ flux (green line). The lower panels (c) show the sum of the emissions of monoterpenes (green dots), sesquiterpenes (red dots) and linalool (blue dots). The values on the x-axis are day-of-year in 2006.

increase being as high as $7.1^{\circ} \mathrm{C}$. This should be taken into account when interpreting the regional emission values.

\section{Results and discussion}

\subsection{Measured emissions}

Mountain birches were found to emit large amounts of monoand sesquiterpenes. In addition, linalool emission was found to be substantial, about half of the monoterpene emission. Isoprene emission was negligible. Examples of the emissions of the different VOC groups are shown in Fig. 1 together with records of temperature, light intensity and net ecosystem $\mathrm{CO}_{2}$ exchange, obtained from an eddy covariance flux tower at the same site. From these results it is apparent that the emissions are strongly dependent on the temperature inside the chamber.

The average emission spectra of the most abundant compounds during the measurements in 2006 and 2007 are shown in Fig. 2. When considering single monoterpene species, the monoterpene emission was dominated by sabinene. Other abundant monoterpenes were ocimene, trans-ocimene, terpinolene and $\alpha$-pinene. The same com- pounds were identified by Hakola et al. (2001) from the emissions of downy birch in southern Finland. The total monoterpene emission averaged over all trees in 2006 was $1100 \mathrm{ng} \mathrm{g}_{\mathrm{dw}}^{-1} \mathrm{~h}^{-1}\left(2.2 \mathrm{pmol} \mathrm{g}_{\mathrm{dw}}^{-1} \mathrm{~s}^{-1}\right)$, ranging from 0 to $14000 \mathrm{ng} \mathrm{g}_{\mathrm{dw}}^{-1} \mathrm{~h}^{-1}$. In 2007 the average sum was almost equal, $1200 \mathrm{ng} \mathrm{g}_{\mathrm{dw}}^{-1} \mathrm{~h}^{-1}\left(2.5 \mathrm{pmol} \mathrm{g}_{\mathrm{dw}}^{-1} \mathrm{~s}^{-1}\right)$, and varied between 0 and $4000 \mathrm{ng} \mathrm{g}_{\mathrm{dw}}^{-1} \mathrm{~h}^{-1}$.

In 2006 sesquiterpenes were emitted in high amounts, the average total emission being $2700 \mathrm{ng} \mathrm{g}_{\mathrm{dw}}^{-1} \mathrm{~h}^{-1}$ (3.7 $\left.\mathrm{pmol} \mathrm{g}_{\mathrm{dw}}^{-1} \mathrm{~s}^{-1}\right)$. The sesquiterpene emission varied between 0 and $31000 \mathrm{ng} \mathrm{g}_{\mathrm{dw}}^{-1} \mathrm{~h}^{-1}$. The dominant sesquiterpene compound was $\alpha$-farnesene, followed by $\beta$-caryophyllene. In 2007 the sesquiterpene emission was reduced to a fraction of the emission in 2006. In 2007 the average total emission was only $16 \mathrm{ng} \mathrm{g}_{\mathrm{dw}}^{-1} \mathrm{~h}^{-1}\left(0.022 \mathrm{pmol} \mathrm{g}_{\mathrm{dw}}^{-1} \mathrm{~s}^{-1}\right)$, which is less than $1 \%$ of that in the previous year. The dominating compound was $\beta$-caryophyllene while $\alpha$-farnesene was not observed at all.

The tree-to-tree variation of the emissions was high (see Table 1). Trees 1 and 4 had almost equal emissions of mono- and sesquiterpenes. Trees 2 and 3 had somewhat smaller monoterpene emissions but significantly higher sesquiterpene emissions than the other trees. Mountain 
Table 1. The results of the nonlinear regression analysis of the monoterpene and sesquiterpene emission rates using both the temperature dependent TEMP algorithm (Guenther et al., 1993) and the temperature and light dependent G97 algorithm (Guenther et al., 1993; Guenther 1997). $E_{0}\left(\mathrm{ng} \mathrm{g}_{\mathrm{dw}}^{-1} \mathrm{~h}^{-1}\right)$ are the emission potentials at temperatures of $20^{\circ} \mathrm{C}$ and $30^{\circ} \mathrm{C}$ and incident PPFD of $1000 \mu \mathrm{mol}_{\text {photons }} \mathrm{m}^{-2} \mathrm{~s}^{-1}$ in the G97 algorithm. $\beta\left({ }^{\circ} \mathrm{C}^{-1}\right)$ is the coefficient describing the strength of the temperature dependence in the TEMP algorithm. $R^{2}$ is the regression statistic and the $P$ values for fitted $\beta$ are indicated using asterisks. The values in the parentheses are the standard errors. $\mathrm{N}$ indicates the number of chamber closures in each subset.

\begin{tabular}{|c|c|c|c|c|c|c|c|c|c|c|}
\hline \multirow[b]{2}{*}{ Measurements } & \multicolumn{3}{|c|}{$\begin{array}{c}\text { TEMP, } \\
\beta_{M T}=0.09^{\circ} \mathrm{C}^{-1}, \\
\beta_{S Q T}=0.18^{\circ} \mathrm{C}^{-1}\end{array}$} & \multicolumn{4}{|c|}{$\begin{array}{c}\text { TEMP, } \\
\text { variable } \beta\end{array}$} & \multicolumn{3}{|c|}{ G97 } \\
\hline & $E_{0,20^{\circ} \mathrm{C}}$ & $E_{0,30^{\circ} \mathrm{C}}$ & $R^{2}$ & $\beta$ & $E_{0,20^{\circ} \mathrm{C}}$ & $E_{0,30^{\circ} \mathrm{C}}$ & $R^{2}$ & $E_{0,20^{\circ} \mathrm{C}}$ & $E_{0,30^{\circ} \mathrm{C}}$ & $R^{2}$ \\
\hline \multicolumn{11}{|l|}{$\begin{array}{l}\text { Birch 1, }(\mathrm{N}=21) \\
\text { 28.6.-21.7.2006 }\end{array}$} \\
\hline Monoterpenes & $\begin{array}{l}289 \\
(98)\end{array}$ & $\begin{array}{l}710 \\
(240)\end{array}$ & 0.46 & $\begin{array}{c}0.270 \\
(0.042) \\
* * *\end{array}$ & $\begin{array}{l}191 \\
(47)\end{array}$ & $\begin{array}{l}2850 \\
(698)\end{array}$ & 0.77 & $\begin{array}{l}291 \\
(35)\end{array}$ & $\begin{array}{l}1030 \\
(125)\end{array}$ & 0.62 \\
\hline Sesquiterpenes & $\begin{array}{l}389 \\
(60)\end{array}$ & $\begin{array}{l}2350 \\
(364)\end{array}$ & 0.71 & $\begin{array}{c}0.207 \\
(0.035) \\
* * *\end{array}$ & $\begin{array}{l}374 \\
(90)\end{array}$ & $\begin{array}{l}2820 \\
(679)\end{array}$ & 0.72 & $\begin{array}{l}428 \\
(49)\end{array}$ & $\begin{array}{l}1520 \\
(174)\end{array}$ & 0.63 \\
\hline \multicolumn{11}{|l|}{$\begin{array}{l}\text { Birch 2, }(\mathrm{N}=7) \\
\text { 1.7.-4.8.2006 } \\
\end{array}$} \\
\hline Monoterpenes & $\begin{array}{l}188 \\
(100)\end{array}$ & $\begin{array}{l}461 \\
(246)\end{array}$ & 0.53 & $\begin{array}{c}0.928 \\
(0.229) \\
* *\end{array}$ & $\begin{array}{c}1 \\
(0)\end{array}$ & $\begin{array}{l}1380 \\
(322)\end{array}$ & 0.92 & $\begin{array}{l}137 \\
(26)\end{array}$ & $\begin{array}{l}490 \\
(92)\end{array}$ & 0.62 \\
\hline Sesquiterpenes & $\begin{array}{l}1721 \\
(972)\end{array}$ & $\begin{array}{l}10400 \\
(5880)\end{array}$ & 0.45 & $\begin{array}{c}0.185 \\
(0.189) \\
\text { n.s. } \\
\end{array}$ & $\begin{array}{l}1650 \\
(673)\end{array}$ & $\begin{array}{l}10500 \\
(4280)\end{array}$ & 0.45 & $\begin{array}{l}2540 \\
(694)\end{array}$ & $\begin{array}{c}9050 \\
(2480)\end{array}$ & 0.43 \\
\hline \multicolumn{11}{|l|}{$\begin{array}{l}\text { Birch 3, }(\mathrm{N}=6) \\
2.7 .-29.7 .2006\end{array}$} \\
\hline Monoterpenes & $\begin{array}{c}281 \\
(215)\end{array}$ & $\begin{array}{c}692 \\
(529)\end{array}$ & 0.03 & $\begin{array}{c}0.042 \\
(0.065) \\
\text { n.s. } \\
\end{array}$ & $\begin{array}{c}405 \\
(108)\end{array}$ & $\begin{array}{c}617 \\
(164)\end{array}$ & 0.12 & $\begin{array}{l}195 \\
(38)\end{array}$ & $\begin{array}{c}698 \\
(137)\end{array}$ & 0.00 \\
\hline Sesquiterpenes & $\begin{array}{c}2720 \\
(3010)\end{array}$ & $\begin{array}{c}16500 \\
(18800)\end{array}$ & 0.18 & $\begin{array}{c}0.150 \\
(0.222) \\
\text { n.s. } \\
\end{array}$ & $\begin{array}{c}3530 \\
(2150)\end{array}$ & $\begin{array}{l}15800 \\
(9620)\end{array}$ & 0.18 & $\begin{array}{c}4040 \\
(1780)\end{array}$ & $\begin{array}{l}14400 \\
(6360)\end{array}$ & 0.19 \\
\hline \multicolumn{11}{|l|}{$\begin{array}{l}\text { Birch 4, }(\mathrm{N}=6) \\
\text { 3.7.-5.8.2006 }\end{array}$} \\
\hline Monoterpenes & $\begin{array}{l}4090 \\
(789)\end{array}$ & $\begin{array}{l}10100 \\
(1940)\end{array}$ & 0.73 & $\begin{array}{c}0.193 \\
(0.040) \\
* *\end{array}$ & $\begin{array}{l}1670 \\
(151)\end{array}$ & $\begin{array}{l}11500 \\
(1043)\end{array}$ & 0.94 & $\begin{array}{l}3030 \\
(334)\end{array}$ & $\begin{array}{l}10800 \\
(1190)\end{array}$ & 0.89 \\
\hline Sesquiterpenes & $\begin{array}{l}544 \\
(58)\end{array}$ & $\begin{array}{l}3290 \\
(349)\end{array}$ & 0.95 & $\begin{array}{c}0.242 \\
(0.027) \\
* * *\end{array}$ & $\begin{array}{l}291 \\
(14)\end{array}$ & $\begin{array}{l}3270 \\
(162)\end{array}$ & 0.98 & $\begin{array}{c}853 \\
(112)\end{array}$ & $\begin{array}{l}3040 \\
(401)\end{array}$ & 0.84 \\
\hline \multicolumn{11}{|l|}{$\begin{array}{l}\text { Birch 4, }(\mathrm{N}=16) \\
\text { 16.7.-17.7.2007 }\end{array}$} \\
\hline Monoterpenes & $\begin{array}{l}1690 \\
(333)\end{array}$ & $\begin{array}{l}4160 \\
(818)\end{array}$ & 0.66 & $\begin{array}{c}0.182 \\
(0.026) \\
* * *\end{array}$ & $\begin{array}{l}1620 \\
(353)\end{array}$ & $\begin{array}{c}9970 \\
(2180)\end{array}$ & 0.86 & $\begin{array}{l}1790 \\
(124)\end{array}$ & $\begin{array}{l}6360 \\
(440)\end{array}$ & 0.86 \\
\hline Sesquiterpenes & $\begin{array}{c}25 \\
(11)\end{array}$ & $\begin{array}{l}151 \\
(16)\end{array}$ & 0.87 & $\begin{array}{c}0.248 \\
(0.032) \\
* * * \\
\end{array}$ & $\begin{array}{l}21 \\
(5)\end{array}$ & $\begin{array}{l}255 \\
(60)\end{array}$ & 0.91 & $\begin{array}{l}28 \\
(2)\end{array}$ & $\begin{array}{l}98 \\
\text { (7) }\end{array}$ & 0.87 \\
\hline
\end{tabular}

*** $P<0.001$

** $P<0.01$

$* P<0.05$

n.s. not significant

birch has several phenotypes, from small polycormic (multistemmed) shrubs to large monocormic (single-stemmed) trees (Vaarama and Valanne, 1973). Hybridization with dwarf birch (Betula nana L.) is common and it is one of the factors affecting the growth form. This variation may be one of the factors explaining the differences in the emissions between the trees. Also Hakola et al. (2001) point out the large variation in the emissions between individual downy birch trees.

\subsection{Temperature and light dependence of emission rates}

To study the temperature and light dependence of the VOC emission rates we performed nonlinear regression analysis using two widely applied emission algorithms. TEMPalgorithm (Guenther et al., 1993) is a simple exponential model of the form 


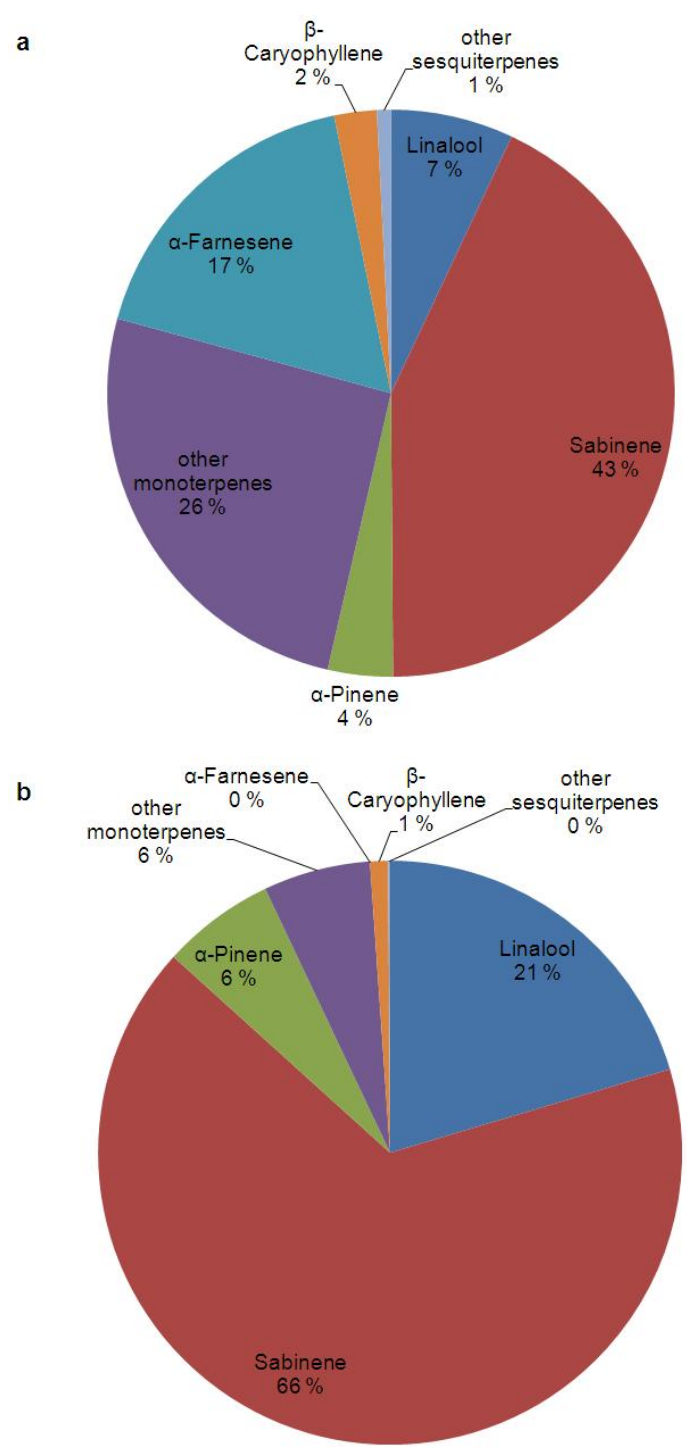

Fig. 2. Mass based emission spectra of VOCs from birch number 4 in (a) 2006 and (b) 2007.

$E=E_{0} \exp \left(\beta\left(T-T_{0}\right)\right)$,

where $E$ is the emission rate at temperature $T, E_{0}$ the emission potential at temperature $T_{0}$, and $\beta$ is an empirical coefficient describing the slope of the temperature dependence. It describes emissions from storage pools inside the plants and it is usually considered as the monoterpene emission algorithm. G97-algorithm (Guenther et al., 1993; Guenther, 1997) is a both temperature and light dependent description of emission rate given by

$E=E_{0} C_{T} C_{L}$,

where $E$ is the emission rate at temperature $T$ and PPFD $L, E_{0}$ the emission potential at temperature $T_{0}$ and PPFD $L_{0}$. The temperature dependence factor $C_{T}$ is an Arrheniustype description of enzymatic activity, having its maximum above $35^{\circ} \mathrm{C} . C_{L}$ is a light dependence factor, saturating at $1000 \mu \mathrm{mol} \mathrm{m}^{-2} \mathrm{~s}^{-1}$. This algorithm is applied to isoprene and monoterpene emissions that are not stored but emitted rather directly from production (e.g. Rinne et al., 2002; Kuhn et al., 2004).

The regression analysis was performed separately for each of the four studied birches and both years. The regression with the TEMP algorithm was performed both with a fixed and a variable strength of the temperature dependence. The selection of fixed $\beta$ value was based on commonly used values for the emission rates. For monoterpenes, $\beta=0.09^{\circ} \mathrm{C}^{-1}$ was used, following the proposal of Guenther et al. (1993) and confirmed by several investigators thereafter for various plant species. For sesquiterpenes, a larger range of values has been reported. The average value from the studies listed by Duhl et al. (2008) is $\beta=0.18^{\circ} \mathrm{C}^{-1}$, which was adopted in this study. A summary of the resulting regression parameters is given in Table 1 .

In Fig. 3a we show the monoterpene emissions of birch 4 as a function of the G97 activity factor $C_{L} C_{T}$. There was a clear difference between the years in these patterns. In 2006, the emissions increased only when $C_{L} C_{T}>0.5$, whereas in 2007 some monoterpene release took place already at lower values of the activity factor $\left(C_{L} C_{T}>0.2\right)$. For sesquiterpenes (Fig. 3b) the observed pattern was possibly reversed, with emissions becoming measurable at lower values of $C_{L} C_{T}$ in 2006 compared to 2007.

Both mono- and sesquiterpene emissions were slightly better explained by the solely temperature dependent algorithm (TEMP). In most cases, allowing the $\beta$ coefficient to vary produced somewhat better regression statistics, especially for the monoterpenes. This method yielded correlation coefficients $R^{2}$ of 0.72 for monoterpenes and 0.65 for sesquiterpenes, averaged over all four trees (Table 1). Forcing the temperature coefficients to be constants, adopted from the literature, decreased the correlation coefficients $R^{2}$ to 0.48 and 0.63 for mono- and sesquiterpenes, respectively.

Between single trees the temperature dependence coefficient $\beta$ varied from $0.04^{\circ} \mathrm{C}^{-1}$ to $0.93^{\circ} \mathrm{C}^{-1}$ for the monoterpene emission and from $0.15^{\circ} \mathrm{C}^{-1}$ to $0.25^{\circ} \mathrm{C}^{-1}$ for the sesquiterpene emission. The temperature coefficients for mono- and sesquiterpene emissions, averaged over all four trees, were $0.32^{\circ} \mathrm{C}^{-1}$ and $0.21^{\circ} \mathrm{C}^{-1}$, respectively. Neglecting the non significant regression results $(P$ value $>0.05$, marked n.s. in Table 1) the temperature coefficients became $0.39^{\circ} \mathrm{C}^{-1}$ and $0.23^{\circ} \mathrm{C}^{-1}$ for mono- and sesquiterpene emissions, respectively. For comparison, Hakola et al. (2001) reported a $\beta$ value of $0.11^{\circ} \mathrm{C}^{-1}$ for monoterpenes and 0.14 $0.22^{\circ} \mathrm{C}^{-1}$ for sesquiterpenes from their downy birch measurements. This temperature coefficient for the sesquiterpene emission rate is in the same range with our results. The monoterpene emission rate, however, seems to be significantly more sensitive to temperature in mountain birch than in downy birch. 

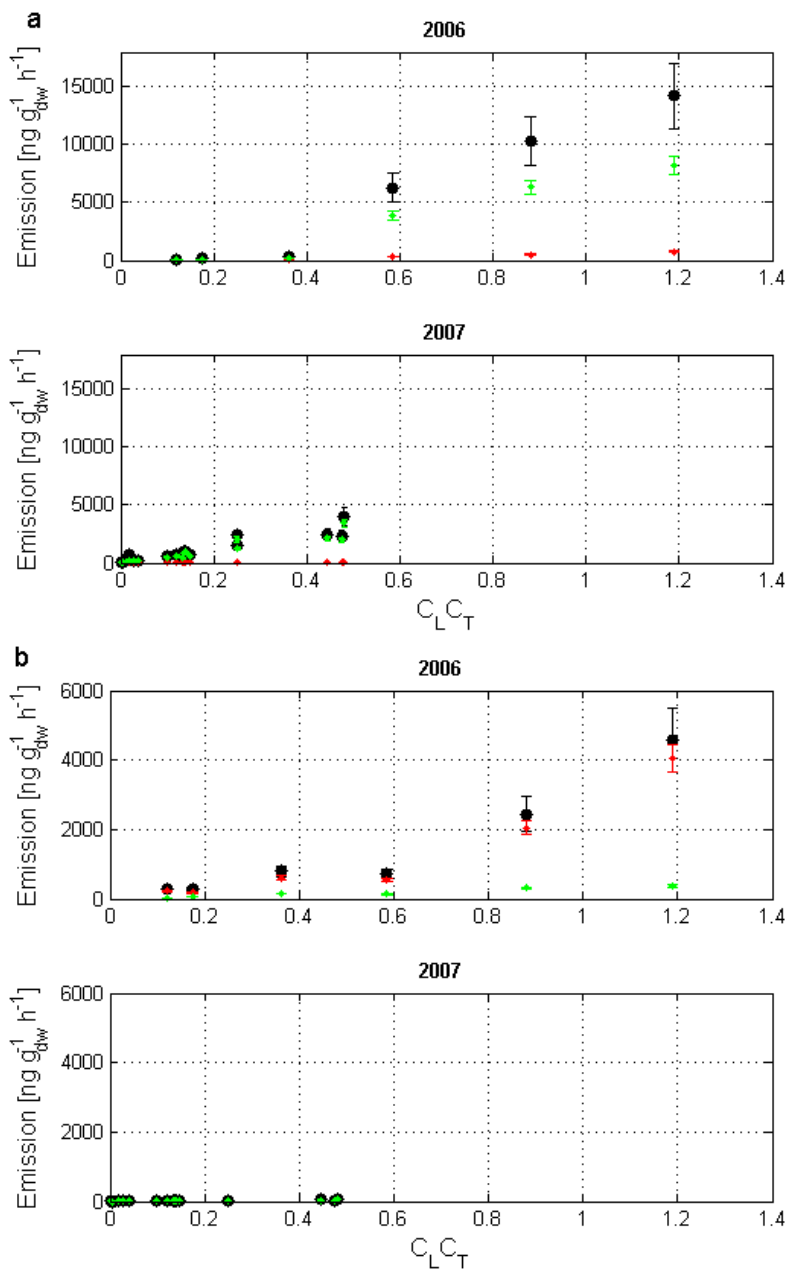

Fig. 3. (a) Monoterpene emissions from the birch number 4 in 2006 and 2007. Black dots indicate the sum of the emissions of all monoterpenes analysed. The red and green dots indicate the emissions of the two most abundant monoterpenes, $\alpha$-pinene and sabinene, respectively. (b) Sesquiterpene emissions from the birch number 4 in 2006 and 2007. Black dots indicate the sum of the emissions of all sesquiterpenes analysed. The red and green dots indicate the emissions of the two most abundant sesquiterpenes, $\alpha$ farnesene and $\beta$-caryophyllene, respectively.

The temperature and light dependent algorithm (G97) was able to reproduce the measurement data reasonably well in most of the cases. This algorithm explicitly sets the emission to zero in total darkness. Similar behaviour was also seen in the present data during night-time for both mono- and sesquiterpenes (see Figs. 1 and 4). This is easy to understand since birches do not have resin ducts where terpenes could be stored in large amounts, and hence most of the emission must come almost directly from synthesis. This was also recently shown for silver birch (Betula pendula L.) by Ghirardo et al. (2009), and emerges as the more general pattern of monoterpene emissions from deciduous trees (Schurgers et al., 2009).
To test whether the terpenes from mountain birch would have a mixed emissions pattern (some from storage, some directly after production), we tried to reproduce the emissions using a linear combination of the TEMP and G97 algorithms, following the approach used by e.g. Steinbrecher et al. (1999). This exercise was conducted only for the data from 2007 when the trees were supposed to function normally, without special resistance to herbivory. The hybrid algorithm slightly improved the fit, as expected. Holzke et al. (2006) used a hybrid algorithm, where they made use of the temperature dependence part of G97 algorithm as the pool emission, instead of the TEMP algorithm. In practice, the difference between these two approaches is small when applied in a narrow temperature range. However, the use of the TEMP algorithm allows setting the temperature dependence factor $\beta$ to a value obtained from the current dataset.

Figure 4 compares the measured monoterpene and sesquiterpene emission rates during the 2007 campaign together with the values obtained from fitting the algorithms. The differences between the measured and predicted emissions are also displayed.

\subsection{Emission potentials}

Emission potentials were calculated for each tree using both TEMP and G97 algorithms (see Table 1). The emission potentials were calculated at the temperatures of $20^{\circ} \mathrm{C}$ and $30^{\circ} \mathrm{C}$, the former temperature giving the correct order of magnitude of the emission rates at the typical maximum temperatures that really occur in the area. The values at $30^{\circ} \mathrm{C}$ are shown for easy comparison to other studies, and these values are discussed below. In all cases, tree-to-tree variations in the emission potentials were high.

Best fits to the data were obtained using the variable temperature coefficients in the TEMP algorithm. The resulting emission potentials for monoterpenes varied from 620 to $12000 \mathrm{ng} \mathrm{g}_{\mathrm{dw}}^{-1} \mathrm{~h}^{-1}$, the average value being $5300 \mathrm{ng} \mathrm{g}_{\mathrm{dw}}^{-1} \mathrm{~h}^{-1}$ $\left(10.8 \mathrm{pmol}_{\mathrm{dw}}^{-1} \mathrm{~s}^{-1}\right)$. Emission potentials for sesquiterpenes varied between 260 and $16000 \mathrm{ng} \mathrm{g}_{\mathrm{dw}}^{-1} \mathrm{~h}^{-1}$, the average value being $6500 \mathrm{ng} \mathrm{g}_{\mathrm{dw}}^{-1} \mathrm{~h}^{-1}\left(8.8 \mathrm{pmol} \mathrm{g}_{\mathrm{dw}}^{-1} \mathrm{~s}^{-1}\right)$. The lowest sesquiterpene emission potential was obtained in 2007 , when the sesquiterpene emission was clearly different from the emission in 2006.

For comparison, Hakola et al. (2001) reported late summer monoterpene emission potentials of downy birch ranging from 170 to $5490 \mathrm{ng} \mathrm{g}_{\mathrm{dw}}^{-1} \mathrm{~h}^{-1}$. For sesquiterpenes, they measured emission potentials in the range $310-6940 \mathrm{ng} \mathrm{g}_{\mathrm{dw}}^{-1} \mathrm{~h}^{-1}$. The emission potentials of both mono- and sesquiterpenes obtained from our measurements are somewhat higher than those measured earlier for downy birch. 

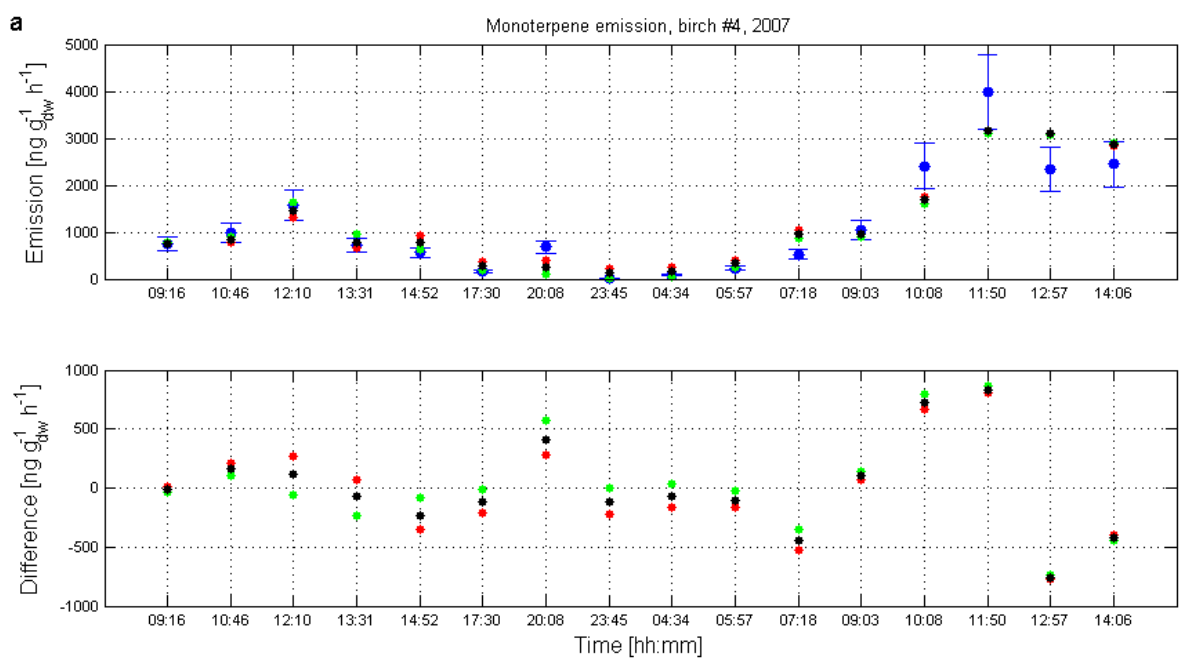

b
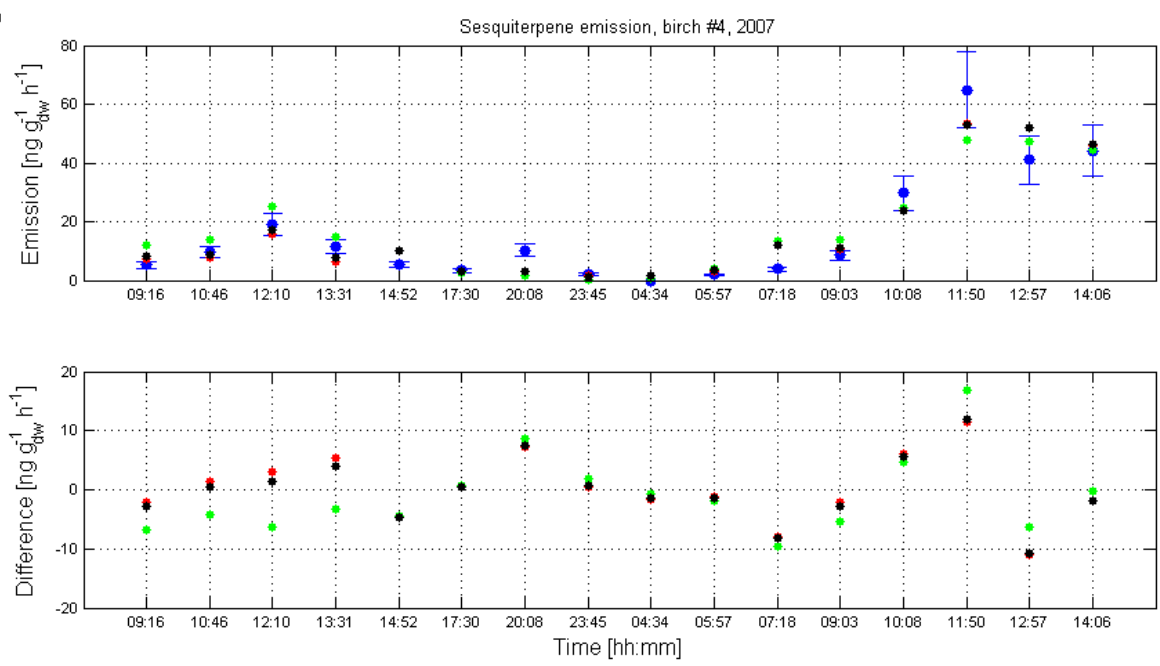

Fig. 4. The measured and predicted emissions of (a) monoterpenes and (b) sesquiterpenes from birch number 4 on 16-17 July 2007. The lower panels show the differences between the measured and predicted emissions. Blue dots are the measured emissions with error bars showing the measurement uncertainty. Red dots display the emission according to the TEMP algorithm, green dots the G97 algorithm, and black dots the hybrid algorithm.

If we force the temperature dependence to a fixed value $\beta=0.09^{\circ} \mathrm{C}^{-1}$, the resulting emission potentials strongly decrease. For example birch number 4, measured in 2007, had the monoterpene emission potential of $10000 \mathrm{ng} \mathrm{g}_{\mathrm{dw}}^{-1} \mathrm{~h}^{-1}$ $\left(20 \mathrm{pmolg}_{\mathrm{dw}}^{-1} \mathrm{~s}^{-1}\right.$ ) when applying the temperature dependence coefficient obtained from the measurements whereas the emission potential was decreased to $4200 \mathrm{ng} \mathrm{g}_{\mathrm{dw}}^{-1} \mathrm{~h}^{-1}$ (8.6 $\mathrm{pmol} \mathrm{g}_{\mathrm{dw}}^{-1} \mathrm{~s}^{-1}$ ) when $\beta$ was set to $0.09^{\circ} \mathrm{C}^{-1}$.

For the G97 algorithm, the monoterpene emission potentials ranged from 490 to $11000 \mathrm{ng} \mathrm{g}_{\mathrm{dw}}^{-1} \mathrm{~h}^{-1}$, with an average of $3900 \mathrm{ng} \mathrm{g}_{d w}^{-1} \mathrm{~h}^{-1}\left(8.0 \mathrm{pmol} \mathrm{g}_{\mathrm{dw}}^{-1} \mathrm{~s}^{-1}\right)$. For sesquiterpene emissions the emission potential varied between 98 and $14000 \mathrm{ng} \mathrm{g}_{\mathrm{dw}}^{-1} \mathrm{~h}^{-1}$, averaging at $5600 \mathrm{ng} \mathrm{g}_{\mathrm{dw}}^{-1} \mathrm{~h}^{-1}$ $\left(7.6 \mathrm{pmol} \mathrm{g}_{\mathrm{dw}}^{-1} \mathrm{~s}^{-1}\right)$. The lowest sesquiterpene emission po- tentials were derived from the 2007 data, and these significantly differed from those of the 2006 data, similar to results obtained by applying the TEMP algorithm.

\subsection{Possible reason for high sesquiterpene emission}

The change in the sesquiterpene emission between the years was dramatic although climatic conditions did not differ heavily between the years. While sampling birch number 4 , the effective temperature sum $\left(+5^{\circ} \mathrm{C}\right.$ threshold, i.e. the sum of the positive differences between diurnal mean temperatures and $+5^{\circ} \mathrm{C}$ ) was between 150 and 320 d.d. (degree days) in 2006 and 270 d.d. in 2007. The effective temperature sum was calculated using the air temperature data from Stordalen mire, located a few hundred meters from 
the birch measurement site. It is well known that stress induced terpenoid emissions can differ from normal emissions in both magnitude and composition. A wealth of literature has demonstrated a change in the emission pattern, particularly increased emissions of the sesquiterpenes $\alpha$-farnesene and $\beta$-caryophyllene, linked to various stress factors of the plants (e.g. Paré and Tumlinson, 1999; Holopainen, 2004). Stress factors include for instance high temperature, drought and mechanical or biological damage. One of the most important stress factors is insect herbivore damage. Herbivore induced VOC emissions may help plants to defend themselves by repelling the insects, disturbing their growth and breeding, or by attracting the natural enemies of the insects. Staudt et al. (2007) studied the effects of gypsy moth (Lymantria dispar $\mathrm{L}$.) feeding on the VOC emission from holm oak (Quercus ilex L.). Feeding induced the emissions of new VOC compounds, consisting of sesquiterpenes, a homoterpene and a monoterpene alcohol. Also undamaged leaves of infested trees emitted new VOCs, but with a different composition and at lower rates.

We thus speculate that one possible reason for the very high sesquiterpene emission in 2006 might be related to herbivory damage through the autumnal moth that occurred at peak outbreak rates in the area in 2004 since, in addition to the instant responses, plants can also have delayed responses. Immunological memory of mountain birch after herbivory by autumnal moth is discussed by Ruuhola et al. (2007). They found out that delayed induced resistance lasted as long as five years. The trees exposed to herbivory five years earlier maintained increased resistance against moth larvae. In addition, some changes in the chemical composition of the leaves was observed. The quercetin to kaemferol ratio was increased whereas phenolic compounds were not significantly affected. The general features of plant memory were recently reviewed by Bruce et al. (2007). They define a plant memory, or stress imprint, as a genetic or biochemical modification of a plant that occurs after stress exposure. These changes in gene expression or plant metabolism cause the plant to respond in a different way to the future stress factors.

Our results provide support from field measurements that changes in the VOC emissions have the potential to last for several years. If a single insect outbreak affects the emissions for about three years and outbreaks occur about once a decade, the mountain birch forest acts as high sesquiterpene emitter during about one third of the years. As sesquiterpenes are known to be important for the formation and growth of secondary organic aerosols (e.g. Bonn and Moortgat, 2003) there may be a link between the occurrence of herbivores and the aerosol particle formation events.

\section{Conclusions}

We measured the branch scale emissions of various VOC compounds from mountain birch, a dominant tree species of the European subarctic ecosystems. The mountain birch leaves were found to emit a large quantity of VOCs, with rates higher than those from downy birch. The data of Tarvainen et al. (2005) suggests that also in case of Scots pine, trees growing in the north may emit more sesquiterpenes compared to trees measured in a mid-latitude growth environment. If that were to emerge as a general feature, it may be, at least partly, explicable by the short but intensive growing season in the north.

We speculate that herbivory damage might be one of the reasons for the dramatic change in the sesquiterpene emissions between the years. Other possible reasons include temperature and drought stress, among several others. However, our dataset is too small to draw any firm conclusions. Herbivory damage is supposed to significantly affect the sesquiterpene emission. Ideally, this variability between the years should be taken into account in emission inventories since even small changes in the emissions of sesquiterpenes have the potential to influence local atmospheric chemistry strongly due to the fact that sesquiterpenes are chemically very reactive. These interactions also raise questions for future climate change impacts of insect outbreaks and herbivory, and their interactions with atmospheric processes. However, today the available data is far too limited to comment on whether such changes will be substantial. While our data indicates possible substantial effects in response to insect attacks, further research is needed for more accurate predictions.

From the present data it is obvious that both monoterpene and sesquiterpene emission of mountain birch approaches zero in the darkness. This suggests that the majority of the emission originates directly from synthesis rather than from storage pools. However, the exact behaviour of the emission is difficult to characterize from field data, as the temperature and light are strongly correlated.

Acknowledgements. This research was supported by the Academy of Finland Center of Excellence program (project 1118615). We acknowledge the Academy of Finland (projects 206162 and 125238) and ACCENT/BIAFLUX for financial support. A. Arneth acknowledges the Swedish Research council for support of the Abisko measurements. Thomas Holst and Torbjörn Johansson are acknowledged for the supporting meteorological and flux data. We are grateful to the staff at Abisko Scientific Research Station for environmental data and support.

Edited by: E. Falge

\section{References}

Alexandersson, H., Karlström, C., and Larsson-McCann, S.: Temperature and precipitation in Sweden 1961-1990, reference normals, SMHI, Norrköping, 88 pp., ISSN 0283-7730, 1991.

Bonn, B. and Moortgat, G. K.: Sesquiterpene ozonolysis: Origin of atmospheric new particle formation from biogenic hydrocarbons, 
Geophys. Res. Lett., 30, 1585, doi:10.1029/2003GL017000, 2003.

Bruce, T., Matthes, M., Napier, J., and Pickett, J.: Stressful "memories" of plants: Evidence and possible mechanisms, Plant Sci., 173, 603-608, 2007.

Bäckstrand, K., Crill, P. M., Mastepanov, M., Christensen, T. R., and Bastviken, D.: Total hydrocarbon flux dynamics at a subarctic mire in northern Sweden, J. Geophys. Res., 113, G03026, doi:10.1029/2008JG000703, 2008.

Duhl, T. R., Helmig, D., and Guenther, A.: Sesquiterpene emissions from vegetation: a review, Biogeosciences, 5, 761-777, 2008, http://www.biogeosciences.net/5/761/2008/.

Ekberg, A., Arneth, A., Hakola, H., Hayward, S., and Holst, T.: Isoprene emission from wetland sedges, Biogeosciences, 6, 601613, 2009,

http://www.biogeosciences.net/6/601/2009/.

Ghirardo, A., Koch, K., Schnitzler, J. P., and Rinne, J.: ${ }^{13} \mathrm{CO}_{2}$ feeding experiments of four common European boreal tree species: ${ }^{13} \mathrm{C}$ incorporation into monoterpenes, in: 4th International conference on proton transfer reaction mass spectrometry and its applications, edited by: Hansel, A. and Dunkl, J., Conference series, Innsbruck university press, 325 pp, ISBN 978-3-90257199-1, 2009.

Guenther, A. B., Zimmerman, P. R., Harley, P. C., Monson, R. K. and Fall, R.: Isoprene and Monoterpene Emission Rate Variability: Model Evaluations and Sensitivity Analyses, J. Geophys. Res., 98, 12609-12617, 1993.

Guenther, A., Hewitt, C. N., Erickson, D., Fall, R., Geron, C., Graedel, T., Harley, P., Klinger, L., Lardau, M., McKay, W. A., Pierce, T., Scholes, B., Steinbrecher, R., Tallamraju, R., Taylor, J. and Zimmerman, P.: A global model of natural volatile organic compound emissions, J. Geophys. Res., 100, 8873-8892, 1995.

Guenther, A.: Seasonal and spatial variations in natural volatile organic compound emissions, Ecol. Appl., 7, 34-45, 1997.

Hakola, H., Rinne, J., and Laurila, T.: The hydrocarbon emission rates of tea-leafed willow (Salix phylicifolia), silver birch (Betuna pendula) and european aspen (Populus tremula), Atmos. Environ., 32, 1825-1833, 1998.

Hakola, H., Laurila, T., Lindfors, V., Hellén, H., Gaman, A., and Rinne, J.: Variation of the VOC emission rates of birch species during the growing season, Boreal. Env. Res., 6, 237-249, 2001.

Hakola, H., Tarvainen, V., Bäck, J., Ranta, H., Bonn, B., Rinne, J., and Kulmala, M.: Seasonal variation of mono- and sesquiterpene emission rates of Scots pine, Biogeosciences, 3, 93-101, 2006, http://www.biogeosciences.net/3/93/2006/.

Haukioja, E., Neuvonen, S., Hanhimäki, S., and Niemelä, P.: The autunmal moth in Fennoscandia, in: Dynamics of forest insect populations. Patterns, causes, implications, edited by: Berryman, A., Plenum Press, New York, 603 pp., ISBN 0-306-42745-1, 163-178, 1988.

Holzke, C., Hoffmann, T., Jaeger, L., Koppmann, R., and Zimmer, W.: Diurnal and seasonal variation of monoterpene and sesquiterpene emission from Scots pine (Pinus sylvestris L.), Atmos. Environ., 40, 3174-3185, 2006.

Holopainen, J. K.: Multiple functions of inducible plant volatiles, Trends Plant Sci., 9, 529-533, 2004.

Isidorov, V. A., Zenkevich, I. G., and Ioffe, B. V.: Volatile organic compounds in the atmosphere of forests, Atmos. Environ., 19, $1-8,1985$.
Juuti, S., Arey, J., and Atkinson, R.: Monoterpene emission rate measurements from a Monterey pine, J. Geophys. Res., 95, 7515-7519, 1990.

Kuhn, U., Rottenberger, S., Biesenthal, T., Wolf, A., Schebeske, G., Ciccioli, P., Rbancaleoni, E., Frattoni, M., Tavares, T. M., and Kesselmeier, J.: Seasonal differences in isoprene and lightdependent monoterpene emission be Amazonian tree species, Glob. Change Biol., 10, 663-682, 2004.

Kulmala, M., Vehkamäki, H., Petäjä, T., Dal Maso, M., Lauri, A., Kerminen, V.-M., Birmili, W., and McMurry, P. H.: Formation and growth rates of ultrafine atmospheric particles: a review of observations, J. Aerosol Sci., 35, 143-176, 2004.

König, G., Brunda, M., Puxbaum, H., Hewitt, C. N., Duckham, S. C., and Rudolph, J.: Relative contrubution of oxygenated hydrocarbons to the total biogenic VOC emissions of selected MidEuropean agricultural and natural plant species, Atmos. Environ., 29, 861-874, 1995.

Law, K. S. and Stohl, A.: Arctic Air Pollution: Origins and Impacts, Science, 315, 1537-1540, 2007.

Paré, P. and Tumlinson, J.: Plant volatiles as a defence against insect herbivores, Plant Physiol., 121, 325-331, 1999.

Piccot, S., Watson, J., and Jones, J.: A global inventory of volatile organic compound emissions from anthropogenic sources, J. Geophys. Res., 97, 9897-9912, 1992.

Rinne, J., Guenther, A., Greenberg, J., and Harley, P.: Isoprene and monoterpene fluxes measured above Amazonian rainforest and their dependence on light and temperature, Atmos. Environ., 36, 2421-2426, 2002.

Ruuhola, T., Salminen, J.-P., Haviola, S., Yang, S., and Rantala, M. J.: Immunological memory of mountain birches: Effects of Phenolics on performance of the autumnal moth depend on herbivory history of trees, J. Chem. Ecol., 33, 1160-1176, 2007.

Schurgers, G., Arneth, A., Holzinger, R., and Goldstein, A. H.: Process-based modelling of biogenic monoterpene emissions combining production and release from storage, Atmos. Chem. Phys., 9, 3409-3423, 2009, http://www.atmos-chem-phys.net/9/3409/2009/.

Simpson, D., Winiwarter, W., Börjesson, G., Cinderby, S., Ferreiro, A., Guenther, A., Hewitt, C. N., Janson, R., Khalil, M. A. K., Owen, S., Pierce, T. E., Puxbaum, H., Shearer, M., Skiba, U., Steinbrecher, R., Tarrason, L. and Öquist, M. G.: Inventorying emissions from nature in Europe, J. Geophys. Res., 104, 81138152, 1999.

Staudt, M. and Lhoutellier, L.: Volatile organic compound emission from holm oak infested by gupsy moth larvae: evidence for distinct responses in damaged and undamaged leaves, Tree Physiol., 27, 1433-1440, 2007.

Steinbrecher, R., Hauff, K., Hakola, H., and Rössler, J.: A Revised Parametrisation for Emission Modelling of Isoprenoids for Boreal Plants, in: Biogenic VOC emissions and photochemistry in the boreal regions of Europe, edited by: Laurila, T. and Lindfors, V., Air pollution research report No 70, Commission of the European Communities, Luxembourg, 158 pp., ISBN 92-828-6990-3. 29-43, 1999.

Svenningsson, B., Arneth, A., Hayward, S., Holst, T., Massling, A., Swietlicki, E., Hirsikko, A., Junninen, H., Riipinen, I., Vana, M., dal Maso, M., Hussein, T., and Kulmala, M.: Aerosol particle formation events and analysis of high growth rates observed above a subarctic wetland-forest mosaic, Tellus, 60B, 353-364, 
2008.

Tarvainen, V., Hakola, H., Hellén, H., Bäck, J., Hari, P., and Kulmala, M.: Temperature and light dependence of the VOC emissions of Scots pine, Atmos. Chem. Phys., 5, 989-998, 2005, http://www.atmos-chem-phys.net/5/989/2005/.

Tiiva, P., Faubert, P., Micheksen, A., Holopainen, T., Holopainen, J. K., and Rinnan, R.: Warming increases isoprene emission from a subarctic heath, New Phytol., 180, 853-863, doi:10.1111/j.14698137.2008.02587x, 2008.

Trägårdh, I.: Sveriges skogsinsekter, 2nd ed, Hugo Gebers förlag, Stockholm, (in Swedish) 1939.
Tunved, P., Hansson, H.-C., Kerminen, V.-M., Ström, J., Dal Maso, M., Lihavainen, H., Viisanen, Y., Aalto, P. P., Komppula, M., and Kulmala, M.: High Natural Aerosol Loading over Boreal Forests, Science, 312, 261-263, 2006.

Vaarama, A. and Valanne, T.: On the taxonomy, biology and origin of Betula tortuosa Ledeb, Reports from Kevo Subarctic Research Station, 10, 70-84, 1973.

Vuorinen, T., Nerg, A.-M., Vapaavuori, E., and Holopainen, J.: Emission of volatile organic compounds from two silver birch (Betula pendula Roth) clones grown under ambient and elevated $\mathrm{CO}_{2}$ and different $\mathrm{O}_{3}$ concentrations, Atmos. Environ., 39, 1185-1197, 2005. 